Alicja Pietras

Uniwersytet Śląski, Katowice

ORCID: 0000-0002-5562-1221

e-mail: alicja.pietras@us.edu.pl

\title{
Andrzej Jan Noras (1960-2020) Wspomnienie i kilka słów o filozofii mojego nauczyciela
}

4 grudnia 2020 roku zmarł Profesor Andrzej Jan Noras, znakomity historyk filozofii, badacz historii filozofii niemieckiej, jeden z największych znawców filozofii neokantowskiej na świecie. Jako człowieka cechowały go przede wszystkim prawdziwie śląska pracowitość, otwartość i przychylność innym ludziom, a także niezwykłe poczucie humoru.

Profesor Andrzej J. Noras studiował filozofię na Akademii Teologii Katolickiej w Warszawie, gdzie w 1986 roku pod kierunkiem profesora Mieczysława Gogacza obronił pracę magisterską dotyczącą stosunku pojęć istoty i istnienia w ontologii Nicolaia Hartmanna. Stopień doktora nauk humanistycznych zdobył w 1993 roku na Katolickim Uniwersytecie Lubelskim, na podstawie dysertacji dotyczącej Nicolaia Hartmanna koncepcji wolności woli, wypromowanej przez profesora Jerzego Gałkowskiego. W latach 1991-1995 Profesor Noras pracował w Wyższej Szkole Pedagogicznej w Częstochowie. W 1995 roku został zatrudniony na Uniwersytecie Śląskim w Katowicach, gdzie trafił do Zakładu Historii Filozofii pod skrzydła trzeciego - jak zwykł mawiać - swojego wielkiego nauczyciela na literę G: profesora Czesława Głombika. W 2001 roku uzyskał stopień naukowy doktora habilitowanego, w 2008 roku - tytuł naukowy profesora, a w 2015 - stanowisko profesora zwyczajnego. Wykładał również na dwóch innych katowickich uczelniach: Akademii Wychowania Fizycznego im. Jerzego Kukuczki oraz Wyższej Szkole Zarządzania Marketingowego i Języków Obcych. 
Wydał 9 książek, ponad 100 artykułów naukowych, był tłumaczem książek i artykułów z języka niemieckiego. Wypromował 8 doktorów filozofii: Izabelę Krupę-Mażulis, Marcina Furmana, Alicję Pietras, Martę Ples-Bęben, Grzegorza Ziąbskiego, Annę Musioł, Michała Sikorę oraz Artura Jochlika. Poza pracą naukową i dydaktyczną był również głęboko zaangażowany w sprawy organizacyjne i administracyjne Uniwersytetu Śląskiego, pełnił funkcję kierownika Zakładu Historii Filozofii Nowożytnej i Współczesnej (2006-2019), kierownika studiów doktoranckich przy Wydziale Nauk Społecznych (2005-2008), kierownika podyplomowych studiów z filozofii i etyki przy Instytucie Filozofii (2000-2020), prodziekana ds. nauki WNS (2008-2016), prorektora ds. badań naukowych (2016-2020).

Profesora poznałam w 2003 roku, podczas trzeciego roku moich studiów filozoficznych na Uniwersytecie Śląskim w Katowicach. Uczestniczyłam wtedy $w$ prowadzonych przez niego wykładach $\mathrm{z}$ historii filozofii współczesnej oraz translatorium z języka niemieckiego. Jakież było moje zdziwienie, gdy okazało się, że przez cały semestr przetłumaczyliśmy zaledwie kilka stron z przedmowy do pierwszego wydania Krytyki czystego rozumu, staranie omawiając i dyskutując każde poszczególne zdanie. Często przez całe półtorej godziny nie udawało nam się ustalić ostatecznego brzmienia tłumaczenia nawet jednego zdania. Mimo to, wychodząc z zajęć, miałam poczucie, że nauczyłam się dziś dużo więcej niż przez ostatnie trzy lata studiów filozoficznych. Fenomen ten zrozumiałam w pełni dopiero pewien czas później, czytając Autobiografię filozoficzna jednego z najczęściej przywoływanych przez Profesora filozofów - Karla Jaspersa, w której opisuje on, jak uświadomił sobie istotną różnicę między myśleniem czysto naukowym a myśleniem filozoficznym w następujący sposób:

Gdy Niss, spotkawszy mnie kiedyś w klinice, zapytał, jak miał w zwyczaju: Jakie wyniki? - uzmysłowiłem sobie momentalnie (bo właśnie filozoficznie rozmyślałem), że istnieje myślenie $w$ pełni sensowne bez wyników ${ }^{1}$.

Profesor zawsze żywił przekonanie, które także mi było już wtedy bliskie, choć jeszcze nie w pełni świadomie, że - jak pisze drugi z jego największych autorytetów, Nicolai Hartmann:

Błędem jest mniemanie, że tylko „rozwiązania” posuwają wiedzę naprzód - nieunikniony błąd każdego początkującego i adepta. Na ogół jest wręcz przeciwnie: rzekome rozwiązania są spekulatywnymi błędami. Natomiast niestrudzona praca nad samymi problemami [...] ma na-

1 Karl Jaspers, Autobiografia filozoficzna, przeł. Stanisław Tyrowicz (Toruń: Wydawnictwo Comer, 1993), 36. 
prawdę trwała, nieprzemijającą wartość w myślowym dorobku historii filozofii ${ }^{2}$.

Będąc pod głębokim, choć wtedy jeszcze nie w pełni zrozumianym, wrażeniem zajęć translatoryjnych, zaczęłam regularnie uczęszczać na prowadzone przez Profesora seminaria. Pamiętam również doskonale dzień, gdy szłam do sekretariatu Instytut Filozofii Uniwersytetu Śląskiego w celu wyboru promotora mojej przyszłej pracy magisterskiej. Byłam zdecydowana zapisać się na seminarium innego profesora, jednak $-\mathrm{z}$ zupełnie niezrozumiałych dla mnie jeszcze wtedy powodów, kierowana raczej intuicją niż wcześniej racjonalnie podjętą decyzją - gdy pani sekretarka (a trzeba wiedzieć, że była to osoba surowa, z która nie należało zadzierać) zapytała: „Kogo pani wybiera?”, bez zająknięcia, ku własnemu zdziwieniu, odpowiedziałam jasno i wyraźnie: „Profesora Norasa".

Osoba Profesora owiana była, co z pewnością przyznają inni jego uczniowie, pewną legendą. Uważany był on za bardzo wymagającego i surowego nauczyciela. Inny jego uczeń, a mój kolega z czasów pracy na Akademii Pomorskiej w Słupsku, Marcin Furman opowiadał, że wśród studentów z jego rocznika panowało przekonanie, że jeśli zda się egzamin z historii filozofii współczesnej u - wtedy jeszcze - Doktora Norasa, to już można uważać się za magistra filozofii. Profesor bywał szorstki, zawsze mówił, co myśli, i mimo że - co odkryłam dopiero po latach - był bardzo przychylny innym ludziom, niezwykle rzadko wprost okazywał empatię. Z tego też powodu wielu studentów zwyczajnie bało się zdecydować na współpracę z nim. Jednak każdy, kto był częścią słynnych seminariów: magisterskiego czy doktorskiego, z pewnością do dziś pamięta te spotkania. $\mathrm{W}$ czasach, gdy bywałam tam regularnie, podczas pisania pracy magisterskiej, a potem doktorskiej (musiały to być więc lata 2004-2008), na seminarium uczęszczali m.in. Tomasz Bańczyk, Dorota Barcik, Ewa Chudyba, Marcin Furman, Dariusz Kiełbasiński, Tomasz Kubalica, Anna Musioł, Piotr Nowara, Marta Ples czy Aleksandra Siedlecka. Ten skład od czasu do czasu się zmieniał - jedni odchodzili, pojawiali się nowi. Zazwyczaj te same osoby uczestniczyły również w seminarium ogólnofilozoficznym, początkowo prowadzonym jeszcze przez profesora Czesława Głombika, a po jego odejściu na emeryturę przez Profesora Norasa, a także we wspomnianym już translatorium z języka niemieckiego. Można powiedzieć, że tworzyliśmy w tamtych czasach pewnego rodzaju filozoficzna, jeśli nie wspólnotę, to przynajmniej grupę dyskusyjną. Tak to przynajmniej odczuwaliśmy, my - studenci. Doświadczenie to było dla mnie bardzo ważne, gdyż nauczyło

${ }^{2}$ Nicolai Hartmann, Myśl filozoficzna i jej historia. Systematyczna autoprezentacja, przeł. Jan Garewicz (Toruń: Wydawnictwo Comer, 1994), 79. 
mnie czegoś, czego próbuję dziś - z lepszym lub gorszym skutkiem uczyć własnych studentów i co bez wątpienia nieustannie wykorzystuję w swojej pracy naukowej: najlepszym sposobem filozofowania jest dialog, otwarta, nieskrępowana żadnymi tytułami naukowymi czy - co gorsza - wzajemną rywalizacją otwarta dyskusja. Myślę, że z Profesorem Norasem rozumieliśmy się tak dobrze, gdyż dzieliliśmy przekonanie, któremu bezpośredni wyraz dał również jeden z naszych wspólnych autorytetów filozoficznych, Karl Jaspers, pisząc, że jednym z podstawowych dążeń człowieka obok woli wiedzy jest wola komunikacji.

Poza myślą Jaspersa Profesor zaraził mnie również, a może przede wszystkim, filozofią Nicolaia Hartmanna. W 2006 roku pod jego kierunkiem napisałam i obroniłam pracę magisterską dotyczącą problemu poznania w filozofii Kanta i właśnie - poznanego dopiero na wykładach Profesora Norasa - Nicolaia Hartmanna. W czasie jej pisania byłam już słuchaczką studiów doktoranckich z socjologii i planowałam napisanie doktoratu dotyczącego filozoficznych założeń jednej z socjologicznych koncepcji kultury pod kierunkiem drugiego mojego znakomitego nauczyciela, Profesora Wojciecha Świątkiewicza. Im bardziej jednak posuwały się naprzód moje analizy dotyczące teoretycznych założeń socjologii kultury, tym bardziej uświadamiałam sobie znaczenie i rolę koncepcji tworzonych przez tych wszystkich filozofów, którymi zajmował się Profesor Noras. Zaczęłam przeczuwać, że muszę na pewien czas odłożyć doktorat z socjologii i zająć się jeszcze bardziej pogłębionymi studiami filozoficznymi. W pewnym momencie, nie wiedząc już, co zrobić, umówiłam się na spotkanie z oboma moimi nauczycielami. Bardzo obawiałam się rozmowy z nimi i oczekiwałam raczej negatywnej reakcji na mój brak zdecydowania. Ku mojemu zdziwieniu, gdy - równocześnie analizując całą sytuację w myślach i wypowiadając te myśli na głos stwierdziłam, że napiszę jednak doktorat z filozofii, obaj Profesorowie bez zbędnych pytań i dyskusji przystali na mój pomysł i z dnia na dzień z doktorantki socjologii stałam się doktorantką filozofii.

O Profesorze Norasie mogę z pełnym przekonaniem powiedzieć, że był moim nauczycielem i mistrzem. Wywarł bardzo duży wpływ na moje myślenie i filozofię. Nauczył mnie, jak olbrzymią rolę przy prowadzeniu badań filozoficznych odgrywa historia filozofii, mimo że moje sympatie naukowe $\mathrm{z}$ początku $\mathrm{w}$ ogóle nie kierowały się $\mathrm{w}$ tę stronę. Trafiwszy do filozofii z jednej z nauk szczegółowych (w celu głębszego filozoficznego przemyślenia i ugruntowania jej teoretycznych podstaw), nigdy nie uważałam się za historyka filozofii. Profesor zaraził mnie jednak pasją do historii filozofii niemieckiej, zwłaszcza do całej tradycji niemieckiej filozofii transcendentalnej, od Kanta przez idealizm niemiecki, neokantyzm, aż po filozofów, których nazywał postneokantystami. Zainteresowany zagadnieniem periodyzacji dziejów filozofii, stworzył i rozpowszechnił ten termin w celu wskazania konieczności 
wyodrębnienia nowego stadium w rozwoju myśli pokantowskiej. Postneokantystami nazywał tych filozofów, którzy porzucając dominującą na przełomie XIX i XX wieku neokantowską epistemologiczna interpretację myśli Kanta, intepretowali Kanta ontologicznie i głosili konieczność tworzenia nowej krytycznej (a więc uwzględniającej całą Kantowską i pokantowską krytykę poznania) ontologii: Nicolaia Hartmanna, Martina Heideggera, Karla Jaspersa, Heinza Heimsoetha i Richarda Hönigswalda. Posługując się tym terminem, Profesor pragnął również podkreślić, z czym nigdy się nie krył, że - uznawany powszechnie za niepowtarzalny - Heideggerowski projekt ontologii fundamentalnej był $\mathrm{w}$ istocie tylko jednym, i to w dodatku nie pierwszym, z projektów związanych z tzw. zwrotem ontologicznym lat dwudziestych XX wieku. Stosunek Profesora Norasa do filozofii, a w jeszcze większym stopniu do osoby Martina Heideggera był bowiem zawsze wyjątkowo krytyczny. Znając doskonale, w najdrobniejszych szczegółach historię filozofii niemieckiej tamtego okresu, nie tylko nie podzielał przekonania o wyjątkowości myśli Heideggera, wykazując zawsze, że znaczną część swoich pomysłów filozof ten zaczerpnął, bardzo często wcale się do tego nie przyznając, od swoich nauczycieli i kolegów (tu głównie od Emila Laska); twierdził również zawsze otwarcie, że nie poważa Heideggera jako człowieka. Było to spowodowane głęboko żywionym przez niego przekonaniem, że od filozofa powinno wymagać się więcej w zakresie etyczności jego własnego postępowania niż przykładowo od fizyka czy biologa. Profesor miał do zarzucenia Heideggerowi przede wszystkim dwie rzeczy: pierwszą było to, że Heidegger nie był uczciwy w stosunku do swoich przyjaciół (np. Jaspersa), kolegów (np. Laska) czy nauczycieli (Husserla i neokantystów) - wszystko, co o nim wiemy, wskazuje, że był tak bardzo zapatrzony w siebie i w swoją karierę, że zapominał o nich wtedy, kiedy uczciwy człowiek powinien pamiętać, jak wiele im zawdzięcza. Drugi, równie ważny - a filozoficznie może i ważniejszy - zarzut dotyczył sposobu wyrażania swoich myśli przez Heideggera. Zdaniem Profesora Heidegger nie dbał o to, by być zrozumianym przez innych. Cechowała go niewątpliwe wola wiedzy, jednak niewystarczająco dbał o realizację drugiej, wymienianej przez Jaspersa potrzeby ludzkiej - woli komunikacji. Filozofia powinna być intersubiektywnie komunikowalna, a tym, który powinien o to dbać, jest autor - to słowa, które słyszałam z ust Profesora zawsze, gdy pojawiał się temat Heideggera.

Profesor Noras zawsze podkreślał, że istnieje nierozerwany związek pomiędzy myślą danego filozofa a jego życiem. Uważał, że związek ten powinien zachodzić w obie strony. Nie powinno więc być tak, a przynajmniej każdy szanujący się filozof powinien starać się, aby tak (w jego przypadku) nie było, że - jak podobno miał kiedyś powiedzieć jeden z największych aksjologów XX wieku, Max Scheler, gdy zarzucono mu, iż sam nie żyje zgodnie z wartościami, które głosi - „drogowskaz sam 
nie podąża droga, którą wskazuje". Jeżeli więc Profesorowi bliżsi od Heideggera byli Jaspers czy Hartmann, to w dużej mierze dlatego, iż z tego, co wiemy o ich życiu, wynika, że sami postępowali zgodnie z tym, co głosili.

Profesor Andrzej Noras zawsze uważał filozofię za naukę i zawsze bronił jej naukowości, szukając argumentów za swoim stanowiskiem głównie u Kanta i neokantystów. Sprzeciwiał się wszelkim tym ujęciom filozofii, które sprowadzałyby ją jedynie do pewnego niesprawdzalnego, subiektywnego światopoglądu³. Mimo to filozofia była dla niego czymś dużo więcej niż samą tylko nauką. Była równocześnie także sposobem życia. Śmiało można powiedzieć, że Profesor sam był w pewnym sensie urodzonym filozofem: wszędzie upatrywał filozofii, przy każdej możliwej okazji ją wypróbowywał. Mimo to jego największe naukowe dokonania są związane z historią filozofii. Fakt ten łączy się - jak sądzę - z jego dość skrzętnie ukrywaną przed innymi skromnością i przekonaniem, że dużo większą wartość i znaczenie dla filozofii mają prowadzone przez niego badania myśli innych filozofów niż dzielenie się własną filozofią. Zawsze powtarzał, że zaczynanie filozofowania od swoich przemyśleń bez odwołania się do historii filozofii w większości przypadków przypomina „wywarzanie otwartych już drzwi”. Ponieważ miał jednak wiele własnych, z istoty swej głęboko filozoficznych, przemyśleń i poglądów, tym, którzy byli uważni, przekazywał je w formie swoich słynnych żartów i zawsze wypowiadanych pół żartem, pół serio „powiedzonek”. Jeżeli było się wystarczająco uważnym, trudno było nie odczytać, co myśli o otaczającym nas świecie. Swoimi poglądami dzielił się również poza murami uczelni, przez wiele lat występując w prowadzonej przez panią redaktor Beatę Tomanek audycji w radiowej Trójce.

Profesora cechowała prawdziwie śląska pracowitość, sumienność i uczciwość. Należał do grona tych nielicznych już dziś osób, które nigdy nie pozostawiały bez odpowiedzi żadnego napisanego do nich maila, wiadomości SMS czy nieodebranego połączenia telefonicznego. Zawsze też pozostawał wierny wartościom, w które wierzył. Nie bał się głośno mówić, co myśli, nawet jeśli nie podobało się to większości. Bardzo dużo wymagał, w pierwszej kolejności od siebie, a w drugiej także od innych. Miał dużo zrozumienia dla słabości i trosk innych osób, jednak zazwyczaj nie dawał tego po sobie poznać. Tylko ci, którzy znali go dobrze, byli w stanie zmusić go do okazania empatii, której miał w sobie - jak odkryłam niestety dość późno - niesłychanie wiele. Nie mogę również nie wspomnieć o jednej jego bardzo ważnej cesze: Profesor nie miał w zwyczaju nikogo bezpośrednio i wprost chwalić, tzn. chwalił ludzi bardzo często, ale zawsze pod ich nieobecność. Bardzo długo byłam

${ }^{3}$ Rozumieniu filozofii poświęcona jest w całości jedna z jego książek: Andrzej J. Noras, Kłopoty z filozofia (Katowice: Wydawnictwo Uniwersytetu Śląskiego, 2015). 
przekonana, że to, co robię i piszę, wcale mu się nie podoba, a to dlatego, że zawsze dzielił się ze mną jedynie swoimi krytycznymi uwagami. Trochę później odkryłam jednak, że jeśli chce się dowiedzieć, czy to, co robię w filozofii, mu się podoba, muszę „podpytać” innych. Nigdy nie zapomnę największego komplementu, który spotkał mnie z jego strony. Profesor wysłał mi treść swojego referatu, który miał wygłosić na konferencji w słowackich Koszycach (to był 2017 rok), zatytułowanego Recepcja Heideggera w Polsce; wychwalał w nim moją książkę dotyczącą ontologii Hartmanna i Heideggera. W końcu, po tylu latach wspólnej pracy, doczekałam się komplementu, mimo iż wciąż niewypowiedzianego wprost podczas spotkania w cztery oczy. Myślę, że ta postawa mogła wiele osób zniechęcać do współpracy z nim - choć oczywiście teraz nikt już pewnie tego otwarcie nie przyzna. Piszę to jednak, bo nie uważam tego wcale za wadę, wspominanie której ktoś mógłby uznać w tych okolicznościach za niestosowne. Wręcz przeciwnie: to była jedna z cech jego charakteru, która wraz ze wszystkimi innymi - takimi jak pracowitość, empatia i chęć pomocy innym, a także skrywana pod płaszczykiem ciągłej kpiny z otaczającej go rzeczywistości nieśmiałość wraz z niewyobrażalną wprost pamięcią do szczegółów (dotyczących nie tylko historii filozofii, ale również wielu innych rzeczy, jak np. wyniki wszystkich ostatnich meczów piłkarskich każdej, nawet pięcioligowej drużyny) - składa się na obraz mojego nauczyciela.

Profesor zajmował się przede wszystkim myślą i recepcją Kanta i Hegla, filozofią neokantyzmu badeńskiego i marburskiego ${ }^{4}$. Interesował go problem periodyzacji historii filozofii. Zaproponowany przez niego termin postneokantyzm stanowi jego najbardziej oryginalny wkład do tego zagadnienia, ale przecież nie jedyny. W swojej przetłumaczonej na język niemiecki przez Tomasza Kubalicę Historii neokantyzmu ${ }^{5}$ bardzo skrupulatnie rozważa problem ram czasowych nurtu filozoficznego powszechnie nazywanego neokantyzmem. Jego ostatnie badania $\mathrm{z}$ tego zakresu dotyczyły między innymi relacji między filozofią Cohena i Natorpa. Pokazując, jak bardzo Natorp w późniejszym okresie rozwoju swojej filozofii oddalił się od myśli swojego nauczyciela, podważał słynną, opisywaną przez Tatarkiewicza, wcześniejszą jedności myśli marburskiej. Profesor od lat powtarzał, że ma również rozpoczęta, ale wciąż niedokończoną książkę dotyczącą relacji między późną myślą Husserla

${ }_{4}$ Zob. m.in. Andrzej J. Noras, Kant a neokantyzm badeński i marburski (Katowice: Uniwersytetu Śląskiego, 2000 oraz 2005); Andrzej J. Noras, Kant i Hegel w sporach filozoficznych osiemnastego i dziewiętnastego wieku (Katowice: Wydawnictwo Uniwersytetu Śląskiego, 2007); Andrzej J. Noras, Filozof czystego poznania. Rzecz o Hermannie Cohenie (Katowice: Wydawnictwo Uniwersytetu Śląskiego, 2018).

5 Andrzej J. Noras, Historia neokantyzmu (Katowice: Wydawnictwo Uniwersytetu Śląskiego, 2012); Andrzej J. Noras, Geschichte des Neukantianismus, przeł. Tomasz Kubalica (Berlin: Peter Lang, 2020). 
a filozofią Kanta i neokantyzmu, na którą wielu z nas czekało. Zapowiadał również, że w najbliższym czasie zajmie się zagadnieniem obecności wątków heglowskich w filozofii neokantowskiej.

Drugim, bardzo ważnym dla niego problemem było zagadnienie systemu filozoficznego. Pojawiało się ono prawie na wszystkich jego wykładach i w wielu publikacjach, a ostatecznie zaowocowało także książką zatytułowaną Rozumienie systemu w filozofii pokantowskiej. ${ }^{6}$. W kwestii możliwości i/lub konieczności tworzenia systemu w filozofii Profesor reprezentował pogląd, który nazwać można umiarkowanym, a który wiązał ze sposobem myślenia i filozofowania Kanta i Hartmanna: każda filozofia ze swej natury dąży do uzyskania pewnej systematyczności, ale system należy traktować raczej jako idee regulatywna i z pewnością nie należy od niego zaczynać. Jeżeli w efekcie długoletnich badań decydujemy się w końcu na formułowanie czegoś na kształt systemu, to należy rozumieć go jako system otwarty, czyli taki, który będzie jeszcze nie raz modyfikowany, stosownie do przyszłych osiągnięć poznania naukowego. Tak rozumiany system nie stanowi więc $\mathrm{w}$ żadnym wypadku - i ze względu na ograniczoność ludzkiego poznania nigdy nie będzie stanowił - końca i zwieńczenia poznania, a jedynie zdanie sprawy z obecnego stanu naszej wiedzy.

Kolejnym badanym przez Profesora zagadnieniem był problemem psychologizmu i relacji między psychologią a filozofią. Kwestii tej poświęcona jest książka Problem psychologii w filozofii pokantowskiej ${ }^{7}$. Wychodząc od neokantowskiej krytyki psychologizmu, Profesor widział konieczność krytyki (w sensie kantowskim) psychologii jako samodzielnej dyscypliny naukowej, tzn. wyznaczenia granic psychologii jako kolejnej nauce szczegółowej, która w toku dziejów wyłoniła się z filozofii. Należy zbadać i ustalić jasne granice między psychologią i filozofią (a tym samym między odpowiadającymi im metodami badawczymi) po to, by zapobiec psychologizmowi, który - za Richardem Hönigswaldem - należy rozumieć jako „psychologię na niewłaściwym miejscu”. Zdaniem Profesora zadanie to po dziś dzień nie zostało doprowadzone do końca, o czym świadczyła według niego obserwowana obecnie moda na kognitywistykę, w której psychologia i filozofia nie są wyraźnie od siebie oddzielone. Tuż przed śmiercią Profesor rozpoczął prowadzenie seminarium poświęconego zagadnieniu relacji między psychologią a filozofia, na którym wspólnie ze studentami i doktorantami mieliśmy jeszcze bliżej mu się przyjrzeć. Planował kolejną książkę na ten temat, a z jego

${ }^{6}$ Andrzej J. Noras, Rozumienie systemu w filozofii pokantowskiej (Katowice: Wydawnictwo Uniwersytetu Śląskiego 2016).

7 Andrzej J. Noras, Problem psychologii w filozofii pokantowskiej, Wydawnictwo Uniwersytetu Śląskiego, Katowice 2017. 
słów wynikało, że miał już napisane ponad sto stron, jednak ostatecznie stwierdził, że chce tę sprawę jeszcze raz przemyśleć i przedyskutować.

Zagadnienie relacji między filozofią a naukami szczegółowymi było kwestią którą często z Profesorem poruszaliśmy. Podobnie jak jego interesował problem możliwości wytyczenia metodologiczno-przedmiotowych granic pomiędzy filozofią a psychologia, mnie - w dużym stopniu po wpływem dyskusji z Profesorem - zainteresował analogiczny problem w relacji filozofia-socjologia. Profesor był bardzo krytyczny w stosunku do socjologii jako nauki. Zawsze gdy powracał ten temat (a z racji mojego wykształcenia działo się to często), Profesor nie szczędził okazji, aby wyrazić swoją opinię za pomocą jakiegoś dowcipu. Żartował, że filozofia nie jest już potrzebna, bo niedługo socjologowie rozstrzygną wszystkie istniejące pytania za pomocą ankiet. Ta jego postawa doprowadziła mnie do refleksji, że podobnie jak na przełomie XIX i XX wieku w efekcie usamodzielniania się psychologii pojawił się problem psychologizmu i cały filozoficzno-metodologiczny prąd antypsychologizmu, symptomatycznym dla naszych czasów stał się problem usamodzielnienia się socjologii, generujący na gruncie filozoficznym swego rodzaju spór socjologizmu z antysocjologizmem. Postawę Profesora Norasa interpretowałam więc jako przejaw antysocjologizmu, który nie oznacza jednak odrzucenia sensowności istnienia socjologii jako odrębnej nauki, lecz właśnie odrzucenie socjologizmu - czyli socjologii na niewłaściwym miejscu. Okazuje się więc, że istota sprawy sprowadzała się znowu do problemu granic pomiędzy różnymi dziedzinami nauki. Tym, który pozwalał nam ostatecznie zawsze dojść do porozumienia, okazywał się Nicolai Hartmann ze swoją słynną krytyką wszelkiego rodzaju "-izmów" (takich jak psychologizm czy socjologizm, ale również fizykalizm, biologizm, historycyzm itd.), sprowadzających się do nieuprawnionego przenoszenia zasad i praw odkrytych dla pewnego wąskiego wycinka rzeczywistości na całość bytu ${ }^{8}$. Nie należy jednak zapominać, że problem granic w ogóle był dla Profesora zawsze bardzo ważny. Najlepszym tego dowodem pozostaje to, że wraz z profesorem Krystianem Rolederem (fizykiem z naszego uniwersytetu) utworzył i przez wiele lat prowadził interdyscyplinarne seminarium filozoficzne zatytułowane "Problem granic w filozofii i nauce", na które z wykładami zapraszani byli reprezentanci najróżniejszych dziedzin nauki z całej Polski. Poszukiwanie dialogu z reprezentantami innych nauk jednoznacznie wskazuje, że we wszystkich tych intelektualnych potyczkach dotyczących granic pomiędzy różnymi dziedzinami ludzkiej wiedzy Profesora - w duchu prawdziwie kantowskim - interesowały dużo bardziej granice niż same

8 Zob. Nicolai Hartmann, Nowe drogi ontologii, przeł. Leszek Kopciuch, Artur Mordka (Toruń: Wydawnictwo Rolewski, 1998), 49-55. 
tylko szranki ${ }^{9}$. Dyskutując ze specjalistami z innych dyscyplin, otwierał sobie bowiem możliwość poznania treści znajdujących się po drugiej strony każdej z tych granic. Dla osoby, która ukończyła zarówno studia socjologiczne, jak i filozoficzne, taka postawa była nie do przecenienia. Kolejnym zagadnieniem, które powraca prawie we wszystkich pracach Profesora, jest problem historii filozofii. W całości został mu poświęcony dość obszerny i z tego powodu podzielony na dwie części artykuł „Problem historii filozofii"10. W tym kontekście równie warta uwagi jest jedna z późniejszych książek Profesora Niedocenieni myśliciele - zapomniane historie filozofii ${ }^{11}, \mathrm{w}$ której na przykładzie trzech kompletnie nieznanych prac z kręgu filozofii niemieckiej: Der Aufbau der Systeme (Struktura systemów) Karla Grossa, Denkformen (Formy myślenia) Hansa Leiseganga oraz Das Leben der Philosophen (Życie filozofów) Williego Mooga, Profesor pokazuje, że „historię filozofii można napisać na wiele różnych sposobów”12, gdyż mnóstwo jest możliwości jej rozumienia i uprawiania. Sam fakt poświęcenia swojej uwagi i pracy tym zapomnianym historykom filozofii wskazuje, że Profesor nie rościł sobie pretensji do ostatecznego rozstrzygnięcia, który ze sposobów uprawiania tej dziedziny jest właściwy. Jednak jemu samemu, jak wielokrotnie powtarzał, najbliższa była - ukształtowana w szkole neokantowskiej, a najjaskrawiej zaprezentowana przez Wilhelma Windelbanda, a później Nicolaia Hartmanna - koncepcja historii filozofii jako historii odwiecznych i nieprzemijalnych problemów filozoficznych. Zgodnie $\mathrm{z}$ nią przedmiotem historii filozofii nie są ani gotowe, zbudowane przez poszczególnych filozofów systemy filozofii, ani życie i rozwój myśli poszczególnych filozofów. Przedmiotem historii filozofii jest historia i rozwój problemów filozoficznych, których jednakowoż nie należy mylić z pojęciami filozoficznymi. Trzeba bowiem pamiętać, że jeden i ten sam problem może u różnych myślicieli znajdować swoją konkretyzację w postaci różnych pojęć, podobnie jak pozornie to samo pojęcie może okazywać się nie być tym samym, gdy głębsza analiza sposobu posługiwania się nim przez dwóch różnych myślicieli ujawnia, iż odsyłają jednak do dwóch różnych problemów.

9 Różnicę między granicami a szrankami najlepiej oddaje Kant, pisząc, że „we wszystkich granicach jest także coś pozytywnego, natomiast szranki zawierają same tylko negacje", Immanuel Kant, Prolegomena do wszelkiej przyszłej metafizyki, która będzie mogła wystapić jako nauka, przeł. Artur Banaszkiewicz (Kraków: Wydawnictwo Zielona Sowa, 2005), 109.

10 Andrzej J. Noras, „Problem historii filozofii. Część pierwsza”, Ruch Filozoficzny 1 (2016): 7-27 oraz Andrzej J. Noras, „Problem historii filozofii. Część druga”, Ruch Filozoficzny 2 (2016): 7-27.

11 Andrzej J. Noras, Niedocenieni myśliciele - zapomniane historie filozofii (Katowice: Wydawnictwo Uniwersytetu Śląskiego, 2019).

12 Tamże, 183. 
Rozumienie historii filozofii jako historii problemów filozoficznych zrywa również z przekonaniem, że - inaczej niż w naukach szczegółowych - w filozofii nie można mówić o żadnym rozwoju myśli. Filozofia, jak każda nauka, również się rozwija, jednak - ze względu na specyfikę przedmiotu, który stanowi świat jako całość - jej rozwój przejawia się w inny sposób i jest dużo trudniejszy do uchwycenia. Jak pisze Manfred Brelage: „Każda nowa filozofia wykracza poza poprzednie nie w ten sposób, że je w sobie zawiera [jak dzieje się przypadku niektórych nowych teorii w naukach szczegółowych - A.P.], lecz raczej traktuje je jako postawione naprzeciw nowej filozofii, obok której zachowane zostają wszystkie dotychczasowe"13. Historyk filozofii powinien traktować konkurencyjne teorie raczej jako komplementarne niż całkowicie wzajemnie się wykluczające, pamiętając o tym, że „skoro, zdaniem Hartmanna, epigon jest $\mathrm{w}$ stanie widzieć więcej tylko $\mathrm{z}$ tego powodu, że znajduje się dalej w czasie, to także on nie oddaje $\mathrm{w}$ pełni sprawiedliwości historycznemu bytowi filozofii" ${ }^{14}$. Dwa czynniki, z jednej strony ograniczoność poznawcza samego historyka filozofii, z drugiej fakt nieustannego historycznego rozwoju samych problemów filozoficznych, prowadzą do postulatu pozostawania krytycznym także w stosunku do własnej wizji rozwoju filozofii, jednak bez odrzucania idei i prób jego opisu. Na wykładach, seminariach i w dyskusjach, na określenie postulowanej oraz używanej przez siebie metody uprawiania historii filozofii Profesor posługiwał się często sformułowaniem "myślenie kontekstowe". Myślenie kontekstowe polegać ma na rozważaniu i przedstawianiu myśli danego filozofa w pewnym konkretnym, wybranym i wyraźnie wskazanym jako jeden z możliwych, kontekście - zarówno historycznofilozoficznym, jak również problemowym. Próbą wykorzystania tej metody jest napisana przeze mnie pod kierunkiem Profesora praca doktorska dotycząca ontologii Nicolaia Hartmanna i Martina Heideggera ${ }^{15}$, w której projekty nowych ontologii tych dwóch niemieckich myślicieli przedstawione zostały z punktu widzenia pewnych konkretnych, świadomie i celowo wybranych, kontekstów. Kontekst historycznofilozoficzny stanowią tu filozofia Kanta i neokantyzmu, kontekst problemowy natomiast - pojęcie rzeczy samej w sobie i problem metafizyki. Oczywiście postulat myślenia kontekstowego związany jest $\mathrm{z}$ dążeniem do ujmowania jak

13 „Die jeweils neue Philosophie ist nicht dadurch über die voraufgegangenen hinaus, daß sie diese in sich enthält, sondern sie tritt ihnen als eine neue Philosophie gegenüber, neben der alle bisherigen erhalten bleiben". Manfred Brelage, Studien zur Transzendentalphilosophie (Berlin: Walter de Gruyter, 1965), 24.

14 „Wenn daher nach Hartmann der Epigone schon allein deshalb weiter zu sehen vermag, weil er der zeitlich spätere ist, so wird auch dies dem geschichtliches Sein der Philosophie nicht voll gerecht", tamże, 24.

15 Alicja Pietras, W strone ontologii. Nicolaia Hartmanna i Martina Heideggera postneokantowskie projekty filozofii (Kraków: Universitas, 2012). 
najszerszego kontekstu czyjejś myśli. Ponieważ wiadomo jednak również, że pojedynczy badacz nie jest w stanie rzetelnie i szczegółowo przedstawić wszystkich możliwych kontekstów myśli danego filozofa i z tego powodu zawsze musi dokonać pewnego wyboru, Profesor powtarzał, że warto badać i opisywać te konteksty, które do tej pory były pomijane lub traktowane po macoszemu. Przykładem jest tu właśnie polska recepcja myśli Heideggera, która bardzo długo nie odwoływała się w zadowalający sposób ani do kontekstu neokantowskiego, ani do kontekstu postneokantowskiego (polegającego na zestawieniu myśli Heideggera $\mathrm{z}$ innymi pochodzącymi z lat dwudziestych XX wieku projektami nowych ontologii).

Ostatnim, o którym chcę tutaj wspomnieć, ważnym dla Profesora zagadnieniem filozoficznym, poruszanym jednak dużo częściej w prywatnych rozmowach, na wykładach czy w radiu niż w publikacjach, było zagadnienie wolności, któremu poświęcona była jego praca doktorska zatytułowana Nicolaia Hartmanna koncepcja wolności woli ${ }^{16}$. Nawiązując do Hartmanna, Profesor rozumiał wolność jako nieustannie towarzyszącą człowiekowi i niemożliwą do usunięcia konieczność podejmowania wyborów. Tak rozumiana wolność jawi się raczej jako coś uciążliwego, przed czym - jak wspaniale pokazał to Erich Fromm - ludzie woleliby raczej uciec, niż jako poszukiwany i pożądany, ale niemożliwy do osiągnięcia, stan całkowitej niezależności od wszelkich czynników zewnętrznych. Ontologicznie rzecz ujmując, człowiek zawsze jest wolny, to znaczy posiada wolną (samostanowiącą o sobie) wolę, która wciąż nieodmiennie zmuszana jest do podejmowania różnego rodzaju decyzji, do wyboru pomiędzy różnymi możliwymi, a jednak zawsze dość mocno ograniczonymi przez najróżniejsze czynniki (zarówno zewnętrzne, jak i wewnętrzne) opcjami. Właśnie istnienie tych ograniczeń czyni konieczność wyboru tym uciążliwsza, im mniejszą liczbę rozwiązań mamy do wyboru. Nigdy jednak nie jesteśmy wolni od tak pojętej wolności. Nawet jeżeli uchylamy się od podjęcia jakiejś decyzji, to sam ten akt „uchylania się od wyboru" jest już pewnym wyborem: wyborem pozostawienia spraw w rękach innych osób lub - mówiąc potocznie - losu.

Wraz z takim rozumieniem wolności pojawia się zagadnienie niezbywalnej odpowiedzialności człowieka za własne wybory i całe swoje życie, odpowiedzialności, która zdaje się tym większa, im bardziej jesteśmy świadomi swojej egzystencjalnej struktury i miejsca w świecie. Właśnie dlatego Profesor Noras był tak nieugięty w kwestii niemożliwości całkowitego oddzielenia myśli danego filozofa od dokonywanych przez niego wyborów życiowych. Kto jak kto, ale filozof powinien być świadomy ciążącej na nim odpowiedzialności. Mój nauczyciel stosował

16 Andrzej J. Noras, Nicolaia Hartmanna koncepcja wolności woli (Katowice: Wydawnictwo Uniwersytetu Śląskiego w Katowicach, 1998). 
tę zasadę $w$ równym stopniu do innych, co do samego siebie. Bardzo się cieszę, że nasze drogi życiowe się skrzyżowały - częściowo z powodu niezależnych od nas okoliczności, lecz częściowo również dzięki dokonywanym przez nas wyborom. Był bardzo ważną dla mnie osobą a jego odejście pozostawiło pustkę, której nikt nigdy nie wypełni.

\section{Najważniejsze publikacje Profesora}

\section{Książki}

Filozof czystego poznania. Rzecz o Hermanie Cohenie. Katowice: Wydawnictwo Uniwersytetu Śląskiego, 2018.

Geschichte des Neukantianismus, przeł. Tomasz Kubalica. Berlin: Peter Lang, 2020.

Historia neokantyzmu. Katowice: Wydawnictwo Uniwersytetu Śląskiego, 2012.

Kant a neokantyzm badeński i marburski. Katowice: Wydawnictwo Uniwersytetu Śląskiego, 2000 oraz 2005.

Kant a novokantovstvo - bádenská a marburská škola, przeł. Eugen Andreanský, Vladimir Leško, Pavol Tholt. Košice: Univerzita J. Safarika, 2011.

Kant i Hegel w sporach filozoficznych XVIII i XIX wieku. Katowice: Wydawnictwo Uniwersytetu Śląskiego, 2007.

Kłopoty z filozofia. Katowice: Wydawnictwo Uniwersytetu Śląskiego, 2015.

Nicolaia Hartmanna koncepcja wolności woli. Katowice: Wydawnictwo Uniwersytetu Śląskiego, 1998.

Niedocenieni myśliciele - zapomniane historie filozofii. Katowice: Wydawnictwo Uniwersytetu Śląskiego, 2019.

Problem psychologizmu w filozofii pokantowskiej. Katowice: Wydawnictwo Uniwersytetu Śląskiego, 2017.

Rozumienie systemu $w$ filozofii pokantowskiej. Katowice: Wydawnictwo Uniwersytetu Śląskiego, 2016.

\section{Wybrane artkuły}

„Being Critical, Meaning What?”. Folia Philosophica 34 (2015): 61-76.

"Die Beziehung zwischen Ethik und Logik bei Lotze". W: Denken im Zwiespalt: Zum 200. Geburtstag des Philosophen Rudolph Hermann Lotze. 65-69. Bautzen: Museum Bautzen, 2017.

"Criticism as It Was Understood by Hermann Cohen". W: Thinking Critically: What Does It Mean?: The Tradition of Philosophical Criticism and Its Forms in the European History of Ideas, red. Dariusz Kubok, 127-138. Berlin: De Gruyter, 2018. 
„Filozofia a jej historia: próba charakterystyki”. W: Z problemów wspótczesnej humanistyki, red. Andrzej J. Noras, 49-59. Katowice: Wyższa Szkoła Zarządzania Marketingowego i Języków Obcych, 2003.

„Filozofia a psychologia: próba charakterystyki problemu. Idea. Studia nad struktura i rozwojem pojęć filozoficznych 29, 1 (2017): 5-23.

„Neo-kantianism and Neo-hegelianism. Comments on Neo-philosophy". Ruch Filozoficzny 4 (2016): 55-69.

„Neokantyzm a logika filozofii: szkic problemu”. Folia Philosophica 36 (2016): 29-44.

„Nicolai Hartmanns Metaphysik der Geschichte und der Neukantianismus". W: Der Begriff der Geschichte im Marburger und sudwestdeutschen Neukantianismus, red. Christian Krijnen (Herausgeber), Marc de Launay, 129-144. Würzburg: Königshausen \& Neumann, 2013.

„O periodyzacji filozofii uwag kilka: neokantyzm a postneokantyzm”. Estetyka i Krytyka 26 (2012): 9-19.

"O potrzebie filozofii systematycznej”. Przeglad Filozoficzny 1 (2000): 21-26.

„Philosophy and its history: the validity of Nicolai Hartmann's proposal". W: Slovak and Polish reflections on historical and current philosophical issues, red. Zlatica Plašienková, Barbara Szotek, 32-44. Bratislava: Comenius University, Faculty of Philosophy, 2013.

„Platonizm Nicolaia Hartmanna”. W: Kolokwia Platońskie: Timaios, red. Anna Olejarczyk, Maciej Manikowski, 153-160. Wrocław: Wydawnictwo Uniwersytetu Wrocławskiego, 2004.

„Platoński Teajtet Paula Natorpa". W: Kolokwia Platońskie: Theaititos, red. Artur Pacewicz, 195-200. Wrocław: Instytut Filozofii Uniwersytetu Wrocławskiego, 2007.

„Początki filozofii Cohena a problem psychologii”. Kultura $i$ Wartości 1 (2015): 153-170.

„Pojęcie samoświadomości w filozofii świadomości Paula Natorpa”. Folia Philosophica 32 (2014): 87-106.

„Post-Neo-Kantianism. What is this?”, Wiestnik Rossijskogo Uniwiersitieta Drużby Narodow 1 (2020): 89-98.

„Postneokantyzm wobec Kanta”. Idea. Studia nad struktura i rozwojem pojęć filozoficznych 16 (2004): 79-88.

„Problem historii filozofii. Część pierwsza”. Ruch Filozoficzny 1 (2016): 7-27. "Problem historii filozofii. Część druga". Ruch Filozoficzny 2 (2016): 7-27.

„Recepcja filozofii wczesnego Heideggera w Polsce”. W: Heidegger $v$ Česku, Pol'sku a na Slovensku, red. Vladimír, Leško, Katarína Mayerová, 33-51. Košice: Univerzita Pavla Jozefa Šafárika v Košiciach. Filozofická fakulta, 2018.

„Rickert - der beruhmte Neukantianer oder Neuhegelianer?: Am Rande einer Lekture". Archiwum Historii Filozofii i Myśli Społecznej 59 (2014): 201-210.

„Tezy do problemu historii filozofii”. Roczniki Filozoficzne 1 (2020): 5-32.

"Úvod do novokantovství". Studia Philosophica 57 (2010): 27-35. 


\section{Prace zbiorowe}

Filozofia Kanta i jej recepcja, red. Dariusz Bęben, Andrzej J. Noras. Katowice: Wydawnictwo Uniwersytetu Śląskiego, 2011.

Marburg versus Sudwestdeutschland: Philosophische Differenzen zwischen den beiden Hauptschulen des Neukantianismus, red. Christian Krijnen, Andrzej J. Noras. Würzburg: Königshausen \& Neumann, 2012.

Między kantyzmem a neokantyzmem, red. Andrzeja J. Norasa; przy współudz. Dariusza Kuboka. Katowice: Wydawnictwo Uniwersytetu Śląskiego, 2002.

Neokantyzm badeński i marburski: antologia tekstów, red. Andrzej J. Noras, Tomasz Kubalica. Katowice: Wydawnictwo Uniwersytetu Śląskiego, 2011.

Pytania i perspektywy transcendentalizmu: w dwusetna rocznicé śmierci Immanuela Kanta, red. Andrzej J. Noras. Katowice: Wydawnictwo Uniwersytetu Śląskiego, 2006.

Z problemów współczesnej humanistyki, red. Andrzej J. Noras. Katowice: Wyższa Szkoła Zarządzania Marketingowego i Języków Obcych, 2003.

Z problemów współczesnej humanistyki 2, red. Andrzej J. Noras. Katowice: Wyższa Szkoła Zarządzania Marketingowego i Języków Obcych, 2005.

Z problemów współczesnej humanistyki 3, red. Andrzej J. Noras. Katowice: Wyższa Szkoła Zarządzania Marketingowego i Języków Obcych, 2008.

\section{Tłumaczenia książek}

Hermann Cohen, Kantowska teoria doświadczenia, przeł. Andrzej J. Noras. Kęty: Wydawnictwo Marek Derewiecki, 2012.

Nicolai Hartmann, Wprowadzenie do filozofii: autoryzowany zapis wykładu wygłoszonego w semestrze letnim 1949 roku w Getyndze, przeł. Andrzej J. Noras. Warszawa: Aletheia, 2000.

Herbert Schnadelbach, Hegel: wprowadzenie, przeł. Andrzej J. Noras. Warszawa: Oficyna Naukowa, 2006.

\section{Tłumaczenia artykułów}

Ernst von Aster, "Jak studiuje się filozofię?", przeł. Andrzej J. Noras. Idea. Studia nad struktura i rozwojem pojęć filozoficznych 20 (2008), 127-133.

Ernst Cassirer, „Teoria poznania wraz z pytaniami granicznymi logiki”, przeł. Andrzej J. Noras. W: Neokantyzm badeński i marburski: antologia tekstów, red. Andrzej J. Noras, Tomasz Kubalica, 269-322. Katowice: Wydawnictwo Uniwersytetu Śląskiego, 2011.

Julius Ebbinghaus, „Kant a wiek dwudziesty”, przeł. Andrzej J. Noras. Folia Philosophica 31 (2013): 27-48.

Emil Lask, „Czy istnieje prymat rozumu praktycznego w logice?”, przeł. Andrzej J. Noras. W: Neokantyzm badeński i marburski: antologia tekstów. 153-159. Katowice: Wydawnictwo Uniwersytetu Śląskiego, 2011. 
Paul Gerhard Natorp, „Kant a szkoła marburska”, przeł. Andrzej J. Noras. W: Neokantyzm badeński i marburski: antologia tekstów, red. Andrzej J. Noras, Tomasz Kubalica, 241-266. Katowice: Wydawnictwo Uniwersytetu Śląskiego, 2011.

Herbert Schnadelbach, „Nasz nowy neokantyzm”, przeł. Andrzej J. Noras. Folia Philosophica 24 (2006): 15-33.

Julius Stenzel, „,O problemie historii filozofii. Próba metodologiczna”, przeł. Andrzej J. Noras. Idea. Studia nad struktura i rozwojem pojęć filozoficznych 28 (2016): 386-424.

Wilhelm Windelband, „Historia filozofii”, przeł. Andrzej J. Noras. Idea. Studia nad struktura i rozwojem pojęć filozoficznych 22 (2010): 179-200.

Gerhard Zecha, „Czy etyka jest nauką?”, przeł. Andrzej J. Noras. Folia Philosophica 19 (2001): 155-169.

Kurt Walter Zeidler, „Idealizm a sceptycyzm”, przeł. Andrzej J. Noras, Tomasz Kubalica. Folia Philosophica 33 (2015): 13-26.

Eduard Zeller, „Historia filozofii, jej cele i drogi”, przeł. Andrzej J. Noras. Idea. Studia nad struktura i rozwojem pojęć filozoficznych 23 (2011): 301-310. 